Mini Review

\title{
SOFTWARE USABILITY: CONCEPTS, ATTRIBUTES AND ASSOCIATED HEALTH PROBLEMS
}

\section{Sabīne Grīnberga}

Department of Occupational and Environmental Health, Rīga Stradinšs University, Dzirciema iela 16, Rīga, LV-1007, LATVIA sabine.grinberga@rsu.Iv

\section{Communicated by Modra Murovska}

\begin{abstract}
Digital technologies have opened a large set of opportunities for new electronic services (ecommerce, e-health, e-studies etc.). There are many considerations that need to be made when programmers are building new application software or system software. The software needs to be attractive enough that people want to look at it. It also needs to contain all necessary information that developers want to share with their readers (customers, users) in order to help them achieve the objective for which they came to their website, use their software, or interact with their teaching packages. The oversupply of e-services products has created a need for usability research and development. "Usability means making products and systems easier to use, and matching them more closely to user needs and requirements". Usability is a key concept of the humancomputer interface and is concerned with making computer systems easy to learn and easy to use through a user-centered design process. The in-depth understanding of usability concepts and processes are critical for large-scale acceptance of new e-services and knowledge productivity. Poorly designed software can be extremely annoying to users. Smith and Mayes state that „usability is now recognised as a vital determining factor in the success of any new computer system or computer-based service". Studies have shown that the main health problems of computer users are repetitive strain injuries, visual discomfort and stress-related disorders. Beside other risk factors, such as poor workstation design, uncomfortable work postures, long hours of computer use every day, stress, etc., also poor design and usability of the computer systems, as well as computer technical problems, add to the pressure felt by the user, which may in turn cause stress-related disorders.
\end{abstract}

Key words: software, usability, ergonomics, human computer interaction, health complaints.

\section{USABILITY CONCEPT}

Usability is a crucial factor in the development of any interactive and successful software applications and the most widely used concepts in the software engineering field. Furthermore, it determines the software system's demand and use (Madan and Dabey, 2012). Usability plays a key role in ergonomics aimed to fit office technology to the needs of workers. Ergonomics is closely related to humancomputer interaction, which is an interdisciplinary field in which the way how people interact with computers and all issues related to that interaction are studied (Boivie, 2003). Over the years, these two terms have become more or less interchangeable.

Ergonomics has become of high concern to many international organisations, including the International Organisation for Standards (ISO) (Nielsen, 1993; Jirgensons, 2012). Already in 1991, ISO acknowledged the need for ergonomic regulation of computers, which were progressively becoming a part of office equipment. In the directive of the same year, entitled Ergonomic requirements for office work with visual display terminals, ISO distributed guidelines for human computer interactions (Jirgensons, 2012). ISO defined usability as "the extent to which a product can be used by specified users to achieve specified goals with effectiveness, efficiency and satisfaction in a specified context of use," and the organisation broadened this definition in following directive ISO 9241-11 (1998) (Jirgensons, 2012).

\section{USABILITY ATTRIBUTES}

Usability can be specified and tested by means of a set of operational dimensions or attributes. Usability attributes reviewed in the literature for software include:

- ease of learning (Nielsen, 1990; Shackel, 1991; Reed, 1992; Lindgaard, 1994; Guillemette, 1995);

- ease of use (Nielsen, 1990; Guillemette, 1995);

- easy to remember (Nielsen, 1990); 
- performance effectiveness (Shackel, 1991; Reed, 1992; Lindgaard, 1994);

- few errors and system integrity (Nielsen, 1990; Reed, 1992; Guillemette, 1995);

- flexibility (Shackel, 1991; Lindgaard, 1994; Guillemette, 1995);

- user satisfaction (Shackel, 1991; Reed, 1992; Nielsen, 1993).

\section{RELATIONS BETWEEN SOFTWARE USABILITY AND HEALTH COMPLAINTS OF USERS}

There is a multitude of research and knowledge about the main risk factors in computer-supported work. There is also specific information about the main health problems of computer users. Nevertheless, the occurrence of health problems evidently is increasing rather than decreasing (Boivie, 2003). The field of occupational health is also related to ergonomics and covers to a certain extent the same issues as human computer interaction.

Occupational health addresses health aspects of computer users directly related to computers and software. It also includes health risk factors related to concerns outside the human-computer interaction, such as, work organisation, psychosocial aspects of the work environment etc. (Boivie, 2003). Health complaints in computer supported workplaces are a big problem.

For example, a study on workers in a Swedish Call Centre showed that $86 \%$ of the women and $68 \%$ of the men complained about pain for at least three days in the previous month. About $60 \%$ of the women had suffered from pain in the neck and shoulder region (Norman et al., 2001). In other words, "almost 8 workers out of 10 suffered from pain related to computer use. Another study reports an incidence of $38 \%$ for psychological symptoms and as high as $40 \%$ sick leave in a computer user group with particularly intensive and monotonous computer work (Aronsson et al., 1994). The main health problems of computer users are visual discomfort and repetitive strain injuries, including the mousearm syndrome and problems with wrists and hands, and pain in the neck and shoulders (Aarås et al., 2000). Computer users frequently suffer from stress-related symptoms, such as irritation, fatigue, headaches, and stomach problems (Smith, 1997). While the main risk factors occur in the physical and psychosocial work environment, no less important are risk factors that are related to the computers and the software (Bongers et al., 1993; Aronsson et al., 1994; Smith, 1997; Wigaeus et al., 2001). For example, risk factors related to the computers and the software include dependency on the computer, long response times, breakdowns and poor usability (Aronsson et al., 1994; Smith, 1997; Carayon, 1995; Leino et al., 1999). Poorly designed software, for example, may control the work pace and task order, such that users cannot control their work. The reasons for this may be navigation problems, short-term memory load, inconsistent information coding and problems associated with identifying the status of the process. This in turn may increase cognitive workload, in addition to the general workload, and create stress reactions (Åborg et al., 2003). Mental stress raises muscle tension, and aggravates musculoskeletal pain symptoms (Melin et al., 2001). The combination of physical and mental load may increase blood pressure (Hjortskov et al., 2001). Therefore, it is very likely that there are relations between stress reactions and the design and usability of computer systems. Studies have shown that there is a relationship between usability and the psychological well-being of computer users (Leino et al., 1999).

\section{CONCLUSIONS}

- Usability concepts have been under focus over years and have evolved with different definitions by researchers.

- Different attributes have been built for a clear view of usability and its aspects.

- Usability concepts are in line with technology development and with trends in knowledge society development.

- Usability seems to become critical for successful human computer interaction and physical and psychological well-being of users.

- There is an emerging need for specific usability estimation approaches in different types of e-services.

\section{REFERENCES}

Anonymous (2016). Usability organisations' network. Available at: http://www.usabilitynet.org/management/b_what.htm (accessed 12 April 2015).

Aarås, A., Horgen, G., Ro, O. (2000). Work with the visual display unit: Health consequences. Int. J. Human-Comp. Interaction, 12 (1), 107-134.

Åborg, C., Sandblad, B., Gulliksen, J., Lif, M. (2003). Integrating work environment considerations into usability evaluation methods: The ADA approach. Interact. Comp., 15 (3), 453-471.

Aronsson, G., Dallner, M., Åborg, C. (1994). Winners and losers from computerization: A study of the psychosocial work conditions and health of Swedish state employees. Int. J. Human Comp. Interaction, 6 (1), 17-37.

Boivie, I. (2003). Usability and users' health issues in systems development. Department of Information Technology. IT Licentiate Theses. Uppsala University, Sweden. $10 \mathrm{pp}$.

Bongers, P. M., de Winter, C. R., Kompier, M. A. J., Hildebrandt, V. H. (1993). Psychosocial factors at work and musculoskeletal disease. Scand. J. Work Environ. Health, 19 (5), 297-312.

Carayon, P. (1995). Effect of computer system performance and other work stressors on strain of office workers. Proceedings of the Sixth International Conference on Human-Computer Interaction, Vol. 4, July 9-14, Tokyo. Elsevier Science B.V., Amsterdam, the Netherlands, pp. 693-698.

Chin, J. P., Diehl, V. A., Norman, K. L. (1988). Development of an instrument measuring user satisfaction of the human-computer interface. In: Proceedings of the SIGCHI Conference on Human Factors in Computing Systems (CHI'88), June 15-19, Washington DC, USA. ACM Press, New York, NY, USA, pp. 213-218.

Guilemette, R. A. (1995). The evaluation of usability in interactive information systems. In: Carey, J. M. (Ed.). Human Factors in Information Sys- 
tems: Emerging Theoretical Bases. Ablex Publishing, Norwood, NJ, pp. 207-221.

Hjortskov, N., Blangsted, A. K., Fallentin, N., Ekner, D., Rissén, D., Lundberg, U., Søgaard, K. (2001). The effect of mental and physical stress on the blood pressure response during computer work. In: Sandsjö, L., Kadefors, R. (eds). Prevention of Muscle Disorders in Computer Users. 2nd Procid Symposium: Prevention of Muscle Disorders in Operation of Computer Input Devices. National Institute for Working Life/West. Gothenburg, Sweden, pp. 205-209.

Jirgensons, M. (2012). Towards usability integration into e-learning design. In: Society, Integration, Education. Proceedings of the International Scientific Conference. Part I: School Pedagogy, University Pedagogy, Life-long Education. 25-26 May 2012, Rēzekne, Latvia [Sabiedrība, integrācija, izglītība. Starptautiskās zinātniskās konferences materiāli. I daḷ: Skolas pedagoǵija, Augstskolu pedagogiija, Mūžizglītība. 2012. gada 25.-26. maijs, Rēzekne]. Rēzekne, pp. 291-302.

Leino, T., Ristimäki, T., Huuhtanen, P. (1999). Computer usability problems and psychological well-being. In: Proceedings of the Eighth International Conference on Human-Computer Interaction, Vol. 1, Munich, Germany, 22-26 August. Lawrence Erlbaum Associates Inc., Mahwah, New Jersey, USA, pp. 11-14.

Lindgaard, G. (1994). Usability Testing and System Evaluation: A Guide for Designing Useful Computer Systems. Chapman \& Hall, London. 387 pp.

Madan, A., Dabey, S. K. (2012). Usability evaluation methods: A literature review. Int. J. Eng. Sci. Techn., 04 (2), 590-599.

Melin, B., Rissén, D., Sandsjö, L., Dohns, I., Lundberg, U. (2001). Psychosocial factors, stress reactions and musculoskeletal disorders among female cashiers before and after a work reorganisation; Prevention of muscle disorders in computer users: scientific basis and recommendations. The 2nd PROCID Symposium: Prevention of Muscle Disorders in Computer
Users: Scientific Basis and Recommendations. Kadefors, R, Sandsjö, L. National Institute for Working Life, Stockholm, pp. 215-218.

Nielsen, J. (1990). Designing User Interfaces for International Use (Advances in Human Factors/Ergonomics). North Holland. 244 pp.

Norman, K. (2005). Call centre work: characteristics, physical, and psychosocial exposure, and health related outcomes. Doctoral Thesis. National Institute for Working Life, Linköping University, Sweden. 58 pp.

Norman, K., Floderus, B., Hagman, M., Toomingas, A., Tornqvist, E. W. (2008). Musculoskeletal symptoms in relation to work exposures at call centre companies in Sweden. Work, 30 (2), 201-214.

Preece, J., Rogers, Y., Sharp, H., Benyon, D., Holland, S., Carey, T. (1994). Human-Computer Interaction: Concepts and Design. Addison Wesley, $775 \mathrm{pp}$.

Reed, S. (1992). Who defines usability? You do! PC/Computing, 5 (12). 220-232.

Shackel, B. (1991). Usability: Context, framework, design and evaluation. In: Shackel, B., Richardson, S. (eds.). Human Factors for Informatics Usability. Cambridge University Press, Cambridge, pp. 21-38.

Smith, C., Mayes, T. (1996). Telematics Applications for Education and Training: Usability Guide. Commission of the European Communities, DGXIII 3/c, Commission of the European Communities, Brussels. 2 pp.

Smith, M. J. (1997). Psychosocial aspects of working with video display terminals (VDTs) and employee physical and mental health. Ergonomics, 40 (1), 1002-1015.

Wigaeus Tornqvist, E., Karlkvist, L., Hagberg, M., Hagman, M., Hansson Risberg, E., Isaksson, A., Toomingas, A. (2001). Working conditions and musculoskeletal complaints in computer users. In: Sandsjö, L., Kadefors, R. (eds.). Prevention of Muscle Disorders in Computer Users. 2nd Procid symposium (Prevention of Muscle Disorders in Operation of Computer Input Devices). National Institute for Working Life/West. Gothenburg, Sweden, pp. 12-17.

Received 17 June 2016

\section{PROGRAMMATŪRAS LIETOJAMĪBA UN AR TO SAISTITTĀS VESELĪBAS PROBLĒMAS}

Informācijas un komunikācijas tehnologiijas sniedz iespējas attīstīties dažādiem jauniem elektroniskajiem pakalpojumiem, tādiem kā e-komercija, e-veselība, e-studijas utt. Līdz ar to nepārtraukti pieaug šo pakalpojumu lietotāju skaits un arī pie datora un citām elektroniskajām ierīcēm pavadītais laiks. Tas, savukārt, veicina fiziskās un psihiskās veselības traucējumus, kuru iemesli ir neērtas darba pozas, atkārtotas kustības, psihoemocionālais stress, garas darba stundas. Kaut gan galvenie riska faktori ir sastopami fiziskajā un psihosociālajā darba vidē, ne mazāk svarīga ir lietotāja saskarnes neatbilstība. Slikts datorsistēmu dizains un vāja lietojamība, kā arī tehniskas problēmas, palielina stresu, kas var izraisīt veselības problēmas. Tādējādi var apgalvot, ka programmatūras lietojamībai ir galvenā nozīme ergonomikā, kuras mērkis ir pielāgot biroja tehniku nodarbinātā vajadzībām. Tādēḷ būtiski ir attīstīt lietojamības testēšanas un mērǐ̌anas metodes. 